\title{
EFEKTIFITAS MUSIK DAN RELAKSASI AROMATERAPI LAVENDER DALAM MENURUNKAN TINGKAT KECEMASAN PASIEN DENGAN TINDAKAN PEMBEDAHAN
}

\author{
Erni Buston \\ Politeknik Kesehatan Kementerian Kesehatan Bengkulu, Jurusan Keperawatan, \\ Jalan Indragiri Nomor 03 Padang Harapan Kota Bengkulu \\ buston_87@yahoo.com
}

\begin{abstract}
Anxiety is the most common feeling experienced by patients that have being been taken care in a hospital. They feel worried with their disease more often and what may happen. Anxiety will be more increasing as the patients need to undergo surgery. To reduce this feeling, patients need to get relaxation intervention by using lavender aromatherapy and music. This study aims to analyze the effectiveness of music and lavender aromatherapy in reducing the level of anxiety of patients undergoing surgery. The design of research is Quasi Experiment with pre-test and post-test approach and also uses independent and independent $\mathrm{T}$ test. Non probability sampling with purposive sampling technique is used to determine the samples. The number of samples in each group is 18 respondents. Before the use of lavender intervention, 94,4\% respondents undergo high anxiety and after the treatment, it happens to only $44.4 \%$ respondents. Meanwhile, the treatment of using music is able to reduce the level of anxiety from $94,4 \%$ respondents, before the intervention, to $33,3 \%$ respondents, after the intervention. The statistic test using independent T-test shows p: 0,000 to the group of lavender intervention and p: 0,000 to the group of music. This explains that there is a significant influence of using aromatherapy lavender and music intervention in reducing the level of anxiety in each group. After the treatment, patients feel more relaxed. There is a significant influence of using aromatherapy and music in reducing the level of anxiety in patients undergoing laparatomi surgery. It is important to include intervention of aromatherapy and music as standard operation procedure in reducing the level of anxiety in patients undergoing laparatomi surgery.
\end{abstract}

Key Words: laparatomi, anxiety, lavender aromatherapy, music

Abstrak : Kecemasan merupakan perasaan yang paling umum dialami oleh pasien yang dirawat di rumah sakit, pasien lebih sering merasa cemas terhadap penyakit yang mereka alami dan hal apa yang akan terjadi kepada mereka, kecemasan akan semakin meningkat apabila pasien yang dirawat di rumah sakit harus mengalami proses pembedahan oleh karena itu diperlukan upaya untuk mengurangi tingkat kecemasan dengan memberikan intervensi relaksasi aromaterapi lavender dan musik. Desain penelitian ini adalah Quasi Experiment dengan pendekatan pretest and posttest design. Dengan uji yang digunakan independent test dan independent $T$ test, Cara pengambilan sampel adalah dengan non probability sampling dan tehnik purposive sampling dengan jumlah sampel masingmasing kelompok 18 responden. Sebelum intervensi lavender 94,4\% responden mengalami kecemasan berat dan setelah intervensi lavender terdapat hanya $44,4 \%$ responden yang mengalami kecemasan berat, hasil penelitian pada kelompok intervensi musik sebelum dilakukan intervensi musik terdapat $94,4 \%$ responden dengan kecemasan berat dan setelah intervensi musik terdapat $33,3 \%$ responden mengalami kecemasan berat. Hasil uji statistik menggunakan uji independen $t$ test didapatkan nilai $\mathrm{p}=0,000$ untuk kelompok intervensi lavender dan untuk kelompok musik didapatkan nilai $\mathrm{p}=$ 0,000 hal ini memperlihatkan bahwa ada pengaruh terapi musik dengan intervensi aromaterapi lavender terhadap masing-masing kelompok, dan pasien terlihat lebih rileks setelah dilakukan intervensi. Ada pengaruh intervensi aromaterapi lavender dan terapi 
musik dalam menurunkan kecemasan pada pasien yang melaksanakan pembedahan laparatomi. Diharapkan intervensi aromaterapi dan terapi musik dapat dijadikan protap tetap dalam menurunkan kecemasan pasien yang melaksanakan pembedahan laparatomi

Kata kunc : laparatomi, kecemasan, aromaterapi lavender, musik

Salah satu tindakan pengobatan yang banyak menimbulkan kecemasan adalah tindakan operasi, sampai saat ini sebagian besar orang menganggap bahwa semua pembedahan atau operasi yang dilakukan adalah pembedahan besar terutama bagi mereka yang pertama kali mengalami tindakan pembedahan. Tindakan pembedahan atau operasi merupakan ancaman potensial maupun aktual terhadap integritas seseorang yang dapat membangkitkan reaksi stress fisiologis maupun psikologis (Brunner and Sudart, 1997). Pandangan setiap orang dalam menghadapi pembedahan berbeda, sehingga respon pun akan berbeda, yang mana respon pembedahan pada umumnya menimbulkan ketakutan dan kecemasan pada pasien (Stuart And Sundeen, 1998)

Salah satu metode non farmakologi yang dapat menurunkan kecemasan pasien menghadapi operasi adalah relaksasi nafas dalam dengan menggunakan aromaterapi yang merupakan modifikasi tehnik keperawatan yang dapat dilakukan dalam menurunkan kecemasan(Ani, 2002)

Aromaterapi mempunyai efek positif karena diketahui bahwa aroma yang segar dan harum akan merangsang sensori, reseptor yang pada ahirnya mempengaruhi hipotalamus untuk menimbulkan efek yang kuat terhadap emosi. Aroma yang ditangkap oleh reseptor hidung akan dilanjutkan sebagai informasi ke daerah otak yang mengontrol emosi dan memori kemudian dilanjutkan ke hipotalamus yang merupakan pengatur sistem internal tubuh termasuk sistem seksualitas, suhu tubuh dan reaksi terhadap stress (Shinobi, 2015)

Hasil Penelitian Wening (2014) menyatakan ada perbedaan intensitas nyeri pasca Sectio caesaria sebelum dan sesudah pemberian aromaterapi inhalasi. Hal ini juga didukung oleh penelitian Fenko (2014) yang menyatakan bahwa perbandingan aroma lavender dengan lemon menunjukkan lavender terhadap lemon $\mathrm{p}<0,05$ dengan hasil aroma lavender paling efektif dalam menurunkan kecemasan.

Hal lain yang dapat dilakukan dalam menurunkan kecemasan pasien adalah dengan melakukan tehnik distraksi, tehnik distraksi yang mungkin diberikan pada pasien yang melakukan pembedahan baik sebelum atau setelah operasi untuk menciptakan suasana keadaan tenang dan menurunkan kecemasan adalah dengan mendengarkan musik. Tujuan pemberian terapi musik akan membantu pasien mengekspresikan perasaan, mengurangi ketegangan otot dan menurunkan kecemasan yang mana secara biologis akan meningkatkan energi otot, menyebabkan frekuensi nafas, nadi menjadi teratur tekanan darah menjadi stabil (Djonan, 2006)

Hasil penelitian Pratiwi (2009) tentang pengaruh terapi musik klasik terhadap tingkat kecemasan pasien pre operasi di RSUP DR. Soeradji Tirtonegoro Klaten diketahui bahwa terapi musik klasik mempunyai pengaruh terhadap tingkat kecemasan pre operasi. Sebelum diberikan terapi musik klasik 20 pasien mengalami kecemasan ringan yaitu $64,5 \%, 11$ orang mengalami cemas sedang yaitu $35,5 \%$, setelah diberikan terapi musik 19 pasien tidak mengalami kecemasan yaitu $61 \%$, dan 12 orang mengalami cemas ringan yaitu $39 \%$ responden.

Hal ini sejalan dengan penelitian edi purwanto (2011) menunjukkan bahwa ada pengaruh musik terhadap perubahan intensitas nyeri dan cemas pada pasienpost operasi di ruang bedah RSUP.dr,Sarjito Yogyakarta dengan nilai $\mathrm{p}: 0,000$.

Data nasional yang di dapat di bagian Rekam Medis RSUD Sragen rata-rata tiap bulan pada tahun 2007 terdapat 15-25 penderita yang menjalankan operasi hernia. Berdasarkan catatan keperawatan ruang bedah Mawar, Teratai, dan Wijaya Kusuma RSUD 
Sragen, penderita yang akan dilakukan tindakan pembedahan pada kasus diatas, $10 \%$ dilakukan penundaan karena peningkatan kecemasan. Kecemasan yang terjadi dapat berpengaruh terhadap peningkatan tekanan darah, sehingga tindakan anastesi atau pembedahan ditunda.

Berdasarkan data dari ruang Bedah RSUD Raden Mattaher Jambi diketahui Berdasarkan hasil survei awal yang berhasil di kumpulkan peneliti dari ruang kamar operasi RSUD Dr. M. Yunus didapatkan bahwa pada tahun 2012 terdapat rencana pembedahan sebanyak 1964 pembedahan namun hanya terlaksana sebanyak 1766 pembedahan dan terdapat 198 pembedahan atau 10\% yang di tunda, pada tahun 2013 terencana sebanyak 2364 pembedahan namun yang terlaksana hanya 1984 pembedahan dan yang tertunda 380 pembedahan atau sekitar $16 \%$, pada umumnya pembedahan harus di tunda dikarenakan keadaan pasien yang tidak stabil yaitu tensi meningkat dikarenakan kecemasan sehingga tindakan harus ditunda. Kecemasan yang terjadi dapat berpengaruh terhadap peningkatan tekanan darah, sehingga tindakan anastesi atau pembedahan ditunda. Pada pasien yang bukan dalam keadaan gawat darurat yang akan menjalani operasi besar diharapkan minimal untuk masuk rumah sakit 12 jam sebelum operasi di laksanakan dan operasi kecil 6 jam sebelum di laksanakan hal ini dilakukan agar persiapan yang di lakukan dapat sebaik mungkin.

Berdasarkan hal tersebut tujuan penelitian ini adalah Menganalisis perbandingan efektifitas menggunakan musik dan relaksasi aromaterapi lavender dalam mengurangi tingkat kecemasan pada pasien yang dilakukan pembedahan.

\section{BAHAN DAN CARA KERJA}

Design penelitian yang digunakan dalam penelitian ini adalah Quasi Experiment dengan pendekatan pre test and post test design. Populasi dalam penelitian ini adalah semua pasien yang akan melakukan tindakan pembedahan di RSUD. Dr. M. Yunus Bengkulu. Pengambilan sampel menggunakan simpel random sampling dengan menspesifikan jenis pasien dengan menggunakan kriteria inklusi. Penelitian ini menggunakan 2 kelompok perlakuan, jadi dapat disimpulkan bahwa tiap kelompok dalam penelitian adalah 18 responden sehingga total semua responden sebanyak 36 responden.

Jenis data dari penelitian ini adalah data primer dan data skunder. Alat pengumpulan data dalam penelitian ini menggunakan kuisioner dengan skala HARS, tensi meter jarum, arloji jarum, handphone Android yang berisikan lagu daerah Bengkulu yang memiliki bite 50-70x/menit dengan judul Lalan Belek, Sayang Api Coa Sayang, Anak Kunang, Kebilau Baliak, Sekundang Setuangguan, Masker dengan aroma lavender.

Data dianalisis secara univariat untuk menginterpretasikan mengenai distribusi frekuensi meliputi mean, media, standar deviasi, kesetaraan dan normalitas masingmasing variabel dan data karakteristik. Bivariat untuk melihat perbedaan sebelum dan sesudah intervensi dalam penelitian ini menggunakan uji parametric yaitu paired $t$ test, Independent Samples test, chi square. Multivariat untuk mengetahui variabel independen yang paling signifikan pengaruhnya yang sebelumnya telah dilakukan uji normalitas yang menggukan analisis shapiro wilk Uji yg di gunakan dalam analisis multivariat meliputi repeted anova, dilanjutkan dengan uji Post Hoc-Tukey HSD dan regresi linier sederhana

\section{HASIL}

Grafik 1 Gambar Perubahan Kecemasan Sebelum dan Setelah di berikan Intervensi Lavender dan Intervensi Musik ( $n=36)$

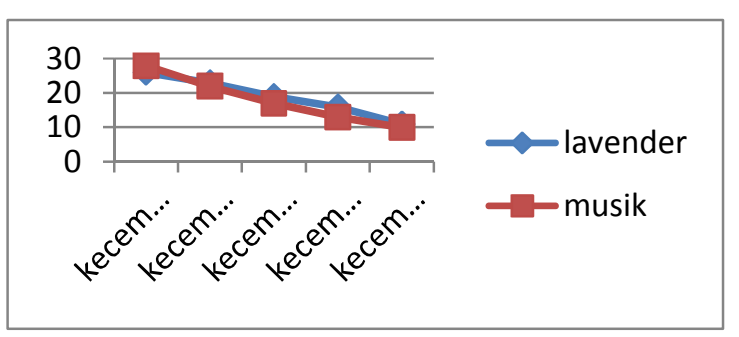


Pada grafik 1 menunjukan Penurunan skor kecemasan lebih banyak terjadi pada kelompok intervensi musik dari pemberian intervensi pertama dan semakin menurun hingga hari ke-3 post operasi laparatomi

Tabel 1 Gambaran Kecemasan Sebelum dan Sesudah dilakukan Intervensi Lavender dan Musik (n=36)

\begin{tabular}{lllllll}
\hline Variabel & \multicolumn{2}{c}{$\begin{array}{c}\text { Pre } \\
\text { intervensi } \\
\text { hari OP }\end{array}$} & \multicolumn{2}{c}{$\begin{array}{c}\text { Post } \\
\text { Intervensi } \\
\text { hari Op }\end{array}$} & \multicolumn{2}{c}{$\begin{array}{c}\text { Pasca OP } \\
\text { Hr I }\end{array}$} \\
& F & \% & F & \% & F & \% \\
\hline $\begin{array}{l}\text { Terapi Lavender } \\
\text { Cemas }\end{array}$ & & & & & \\
sangat berat & & & & & & \\
Cemas berat & 17 & 94,4 & 8 & 44,4 & 2 & 11,1 \\
Cemas & 1 & 56,6 & 10 & 55,6 & 16 & 88,9 \\
sedang & & & & & & \\
$\begin{array}{l}\text { Cemas } \\
\text { ringan }\end{array}$ & & & & & & \\
Terapi Musik & & & & & & \\
Cemas & 1 & 5,6 & 1 & 5,6 & & \\
sangat berat & & & & & & \\
Cemas berat & 17 & 94,4 & 6 & 33,3 & 1 & 5,6 \\
Cemas & & & 11 & 61,1 & 15 & 83,3 \\
sedang & & & & & & \\
Cemas & & & & & & 11,1 \\
ringan & & & & & & \\
\hline
\end{tabular}

Hasil tabel 1 memperlihatkan bahwa pada terapi lavender sebelum dilakukan intervensi didapatkan 17 responden $(94,4 \%)$ mengalami cemas berat dan menurun hingga cemas ringan pada 13 responden $(77,8 \%)$ pada pasca intervensi hari ke III. Hasil penelitian pada kelompok terapi musik sebelum dilakukan intervensi didapat-kan 1 responden $(5,6 \%)$ mengalami cemas sangat berat dan 17 responden $(94,4 \%)$ mengalami cemas berat, hingga intervensi hari ke III post operasi menurun menjadi 14 responden $(77,7 \%)$

Tabel 2 Tebel pengaruh intervensi lavender dan terapi musik terhadap setiap tingkat kecemasan pada pasien dengan operasi laparatomi hari 1, hari ke 2, hari ke 3

\begin{tabular}{lcccc}
\hline \multicolumn{1}{c}{ variabel } & Mean & Sd & T & p \\
\hline Lavender & & & & \\
Pre op-post op & 2,88 & 1,45 & 8,44 & 0,00 \\
Post op -post op hr 1 & 4,00 & 1,74 & 9,70 & 0,00 \\
Post op hr 1-post op hr 2 & 3,05 & 0,873 & 14,8 & 0,00 \\
Post op hr 2-post hr 3 & 5,11 & 2,42 & 8,95 & 0,00 \\
Musik & & & 18,8 & \\
Pre op-post op & 5,88 & 1,32 & & 0,00 \\
Post op -post op hr 1 & 5,22 & 2,26 & 9,78 & 0,00 \\
Post op hr 1-post op hr 2 & 3,50 & 1,33 & 11,0 & 0,00 \\
Post op hr 2-post hr 3 & 3,27 & 1,70 & 8,14 & 0,00 \\
\hline
\end{tabular}

Secara keseluruhan terdapat perbedaan rata-rata kecemasan dan penurunan rerata skor kecemasan pada kelompok lavender dan kelompok intervensi music setelah diberikan intervensi

Tabel 3 Pengaruh intervensi lavender dan terapi musik terhadap setiap tingkat kecemasan pada pasien dengan operasi laparatomi hari 1, hari ke 2, hari ke 3

\begin{tabular}{lcccccc}
\hline \multicolumn{1}{c}{ Variabel } & \multicolumn{2}{c}{ Lavender } & \multicolumn{4}{c}{ Musik } \\
& Mean & SD & Mean & SD & t & p \\
\hline Kecemasana pre & 25,7 & 2,79 & 27,67 & 4,92 & 1,415 & 0,166 \\
Kecemasan Post & 22,8 & 2,72 & 21,78 & 5,19 & 0,804 & 0,427 \\
Kecemasan post 1 & 18,8 & 2,56 & 16,56 & 4,36 & 1,954 & 0,059 \\
Kecemasan post 2 & 15,8 & 2,59 & 13,06 & 3,91 & 2,508 & 0,017 \\
Kecemasan post 3 & 10,7 & 2,63 & 9,78 & 2,98 & 1,008 & 0,321 \\
\hline
\end{tabular}

Tebel diatas menunjukan adanya efektifitas dalam penurunan kecemasan baik pada perlakuan menggunakan aromaterapi lavender maupun terapi musik dimana rerata penurunan lebih banyak terjadi pada kelompok musik dan nilai $\mathrm{p}<0,05$

\section{PEMBAHASAN}

Gambaran karakteristik responden yang menjalani pembedahan laparatomi

Berdasarkan hasil penelitian didapatkan bahwa usia responden berada pada rentang 27-58 tahun, pada kelompok yang diberi intervensi lavender didapatkan bahwa usia rata-rata responden adalah 45 tahun dan kelompok intervensi yang diberikan intervensi musik didapatkan bahwa usia rata-rata responden adalah 47 tahun. Hasil estimasi interval dapat dinyatakan $95 \%$ usia responden pada kelompok intervensi lavender adalah 39 tahun sampai 48 tahun dan kelompok intervensi musik adalah 43 tahun sampai 51 tahun.

Hal ini sejalan dengan pendapat Direja (2003) yang menyatakan bahwa Usia lebih muda diduga lebih mudah terkena stress dan cemas dibandingkan orang yang usianya lebih tua, hal ini dikaitkan dengan pengalaman yang pernah dialami sebelumnya.

Pada variabel lama hari rawat pasien berada pada rentang 3-6 hari rawat, pada kelompok intervensi lavender didapatkan bahwa lama rawat rata-rata 3 hari dan kelompok intervensi musik rata-rata 3 hari. Dengan hasil estimasi interval dapat 
dinyatakan bahwa 95\% diyakini bahwa lama hari rawat responden pada kelompok intervensi lavender adalah 3 hari dan kelompok intervensi musik adalah 3 hari

Penelitian lila dengan judul hubungan kecemasan dengan lama hari rawat pada pasien Infak miocard didapatkan bahwa tidak terdapat hubungan yang siqnifikan antara kecemasan dengan lama hari rawat dengan nilai p: 0,632 (prima, 2012)

Penghasilan responden dalam penelitian ini berada pada rentang 1- 4 juta rupiah. Hasil penelitian menunjukkan bahwa penghasilan responden pada kelompok intervensi lavender didapatkan rata-rata 2,8 juta rupiah dan kelompok intervensi music didapatkan penghasilan rata-rata adalah 3.2 juta rupiah Hasil estimasi interval dinyatakan $95 \%$ diyakini penghasilan responden pada kelompok intervensi lavender adalah 2.3 juta sampai 3.2 juta tahun dan pada kelompok intervensi music adalah 2.9 juta sampai 3.5 juta

Pendapat ini sejalan dengan pendapat Direja (2003) yang menyatakan bahwa ekonomi atau pendapatan yang rendah akan meningkatkan stress seseorang terutama saat menghadapi masalah kesehatan dikarenakan biaya kesehatan yang cenderung tinggi dan membutuhkan waktu yang lama dalam masa pengobatan.

Hasil penelitian rizky dengan judul faktor yang mempengaruhi tingkat kecemasan pasien fraktur pra operasi di RSUD Arifin Achmad pekan baru, terdapat pengaruh pendapatan terhadap kecemasan pasien pra operasi fraktur tulang panjang dengan nilai $p$ value: 0,049 (susanti, 2005)

Tingkat pendidikan responden dalam penelitian ini lebih banyak adalah perguruan tingggi yaitu sebanyak 17 orang (47.2\%), tingkat pendidikan responden pada kelompok intervensi lavender terbanyak adalah PT yaitu 9 orang $(52.9 \%)$ dan pada kelompok intervensi music adalah Perguruan Tinggi sebanyak 8 orang $(47,1 \%)$.

Menurut Direja (2003) pendidikan mempengaruhi tingkat stress dan kecemasan seseorang, hal ini dikarenakan pendidikan umumnya dikaitkan dengan tingkat pengeta- huan seseorang tentang hal atau penyakit yang dihadapinya serta hal yang harus dilakukan dalam menghadapi masalah tersebut

Hasil penelitian rizky, Dkk dengan judul faktor yang mempengaruhi tingkat kecemasan pasien fraktur pra operasi di RSUD Arifin Achmad pekan baru, terdapat pengaruh pendidikan terhadap kecemasan pasien pra operasi fraktur tulang panjang dengan nilai $p$ value: 0,024 (susanti, 2005)

Pekerjaan responden terbanyak adalah bekerja yaitu sebanyak 33 orang (91.2\%), untuk kelompok lavender yang bekerja sebanyak 15 orang $(83.3 \%)$ dan kelompok musik semua responden bekerja yaitu sebanyak 18 orang (100\%)

Status pekerjaan akan mempengaruhi tingkat kecemasan terutama pada pasien yang akan melaksanakan pembedahan, karena pekerjaan akan dikaitkan dengan penghasilan dan kemampuan pasien atau keluarga memenuhi administrasi dalam tindakan operasi, jika seorang pasien tidak memiliki pekerjaan atau pekerjaan yang tidak pasti maka akan mempengaruhi kecemasan pasien terutama dalam masa pengobatan

Hasil penelitian Wayan, dkk dengan judul perbedaan tingkat kecemasan antara pasien laki-laki dan perempuan pada pre operasi laparomi di RSUP Kandou Manado dengan hasil ada perbedaan tingkat kecemasan antara laki-laki dan perempuan dengan nilai $\mathrm{p}$ value :0,024 cemas lebih banyak dialami oleh perempuan

\section{Gambaran kecemasan pasien dengan tindakan pembedahan laparatomi}

Kecemasan dilihat dari mulai pre operasi, kecemasan responden sebelum operasi dalam penelitian ini adalah berada pada rentang 22-41. Hasil penelitian menunjukkan bahwa kecemasan pre operasi pada kelompok intervensi lavender didapatkan rata-rata 26 dan kelompok intervensi musik didapatkan kecemasan rata-rata adalah 28 . Hasil estimasi interval dapat dinyatakan bahwa 95\% diyakini bahwa kecemasan pre operasi responden pada kelompok intervensi lavender adalah 24 sampai 27 dan pada ke- 
lompok intervensi musik adalah 25 sampai 30.

Pada pasien yang mengalami pembedahan kecemasan akan timbul sebagai respon fisiologis yang mempengaruhi tindakan operasi antara lain jantung berdebar, tekanan darah meningkat, denyut nadi menurun, dan nafas menjadi cepat yang nantinya akan menghambat proses pembedahan dan hal itu akan terus berlangsung hingga tindakan operasi selesai (susanti, 2005)

Cemas pre operasi juga dapat mempengaruhi respon fisiologis, emosi dan kognitif, misalnya pasien yang mengalami cemas berat biasanya menyatakan tidak mau dioperasi, selalu menghindar dari pembicaraan hingga mengatakan mereka akan mati dan secara klinis menunjukkan situasi yang serius, bila dihadapkan dengan pasien seperti ini, dokter mungkin akan mempertimbangkan untuk menunda pembedahan sehingga proses pengobatan pun akan tertunda, dan cemas yang tidak diatasi dengan baik akan mempengaruhi respon pasien setelah operasi (prima, 2012)

Berdasarkan hasil penelitian Sawitri dengan judul faktor yang berhubungan dengan kecemasan pasien pre operasi didapatkan bahwa jumlah pasien yang mengalami kecemasan sebelum operasi sebanyak 77,6\% (sawitri, 2012)

Hasil penelitian menunjukkan bahwa pada terapi lavender sebelum dilakukan intervensi didapatkan 17 responden $(94,4 \%)$ mengalami cemas berat dan menurun hingga cemas ringan pada 13 responden $(77,8 \%)$ pada pasca intervensi hari ke III, sedangkan pada terapi musik sebelum dilakukan intervensi didapatkan 1 responden $(5,6 \%)$ mengalami cemas sangat berat dan 17 responden $(94,4 \%)$ mengalami cemas berat, hingga intervensi hari ke III post operasi meurun menjadi 14 responden $(77,7 \%)$

Berdasarkan penelitian masood di civic hospital, pakistan yang dilakukan oleh jawaid et,al tentang kecemasan pre operasi didapatkan bahwa rata-rata responden dalam keadaan cemas dengan nilai mean sebesar 57,65 dan standar deviasi sebesar 25,1, dan dari hasil penelitian tersebut disimpulkan bahwa sebagian besar pasien pre operasi mengalami kecemasan karena takut dengan pembiusan atau anastesi (jawaid, 2006)

Hasil penelitian firman tentang efektifitas musik klasik terhadap penurunan tingkat kecemasan pasien pre operasi di pekalongan didapatkan sebelum terapi didapatkan sebagian besar pasien mengalami cemas sedang, dan setelah dilakukan intervensi terapi musik didapatkan nilai P:0,000 yang artinya terdapat pengaruh intervensi musik dalam menurunkan kecemasan pasien pre operasi (firman, 2012)

\section{Efektifitas Aromaterapi Lavender dalam menurunkan kecemasan pasien dengan tindakan pembedahan}

Secara keseluruhan terdapat perbedaan rata-rata kecemasan dan penurunan rerata skor kecemasan pada kelompok lavender dan kelompok intervensi musik setelah diberikan intervensi, rata-rata terjadi penurunan skor kecemasan pada kelompok yang diberikan terapi lavender adalah sebesar 3 point dan ada perbedaan penurunan skor kecemasan pada kelompok yang diberikan terapi musik sebesar 6 point, dan hasil perubahan dalam kelompok serta antar kelompok menunjukan nilai p: 0,000

Minyak lavender dengan kandungan linaloolnya adalah salah satu minyak aroma terapi yang banyak digunakan saat ini, baik secara inhalasi atau dengan cara pemijatan. Aromaterapi yang digunakan melalui cara inhalasi atau dihirup akan masuk ke sistem limbic dimana nanti aroma akan diproses sehingga kita bisa mencium baunya, saat kita menghirup suatu aroma komponen kimianya akan masuk ke lobus olfaktory kemudian dilanjutkan ke limbic sistem pada otak. Limbic sistem adalah struktur bagian dalam dari bagian otak yang berbentuk seperti cincin yang terletak dibawah koteks serebral. Tersusun dari 53 daerah dan 35 saluran atau tractus yang berhubungan dengannya termasuk amygdala dan Hypocampus. Sistem limbic sebagai pusat nyeri, senang, marah, takut, depresi dan berbagai emosi lainnya, sistem limbic menerima semua informasi dari sistem pendengaran, sistem penglihatan dan sistem penciuman, sistem ini juga dapat 
mengontrol dan mengatur suhu tubuh, denyut jantung, dan pernafasan serta rasa lapar dan haus. Amygdala merupakan bagian sistem limbic yang bertanggung jawab atas respon emosi terhadap aroma ( yasril, 2009)

Aromaterapi mempunyai efek positif karena diketahui bahwa aroma yang segar dan harum akan merangsang sensori, reseptor yang pada ahirnya mempengaruhi hipotalamus untuk menimbulkan efek yang kuat terhadap emosi. Aroma yang ditangkap oleh reseptor hidung akan dilanjutkan sebagai informasi ke daerah otak yang mengontrol emosi dan memori kemudian dilanjutkan ke hipotalamus yang merupakan pengatur sistem internal tubuh termasuk suhu tubuh dan reaksi terhadap stress terutama menjelang tindakan operasi (Shonobi, 2015)

Aromaterapi lavender dapat meningkatkan gelombang alfa dan beta di dalam otak dan gelombang inilah yang akan membantu untuk menciptakan keadaan rileks. Aromaterapi lavender sudah terbukti dapat mengurangi tingkat kecemasan pada pasien yang mendapatkan tindakan infasif, serta dapat menurunkan kecemasan pada pasien hemodialisa, wanita yang menjalani persalinan, berendam dengan menggunakan minyak lavender dapat mengurangi nyeri pada perineum dan kegelisahan pada wanita yang akan melahirkan (Hale, 2015)

Aromaterapi lavender mempunyai efek menenangkan, memberikan ketenangan, keseimbangan, rasa nyaman, rasa keterbukaan dan keyakinan, selain itu juga dapat mengurangi rasa tertekan, stress, rasa sakit, cemas, emosi yang tidak seimbang, histeria, rasa frustasi dan kepanikan serta memberikan rasa relaksasi (Ani, 2002)

Hal lain yang dapat dilakukan dalam menurunkan kecemasan pasien adalah dengan melakukan tehnik distraksi, tehnik distraksi yang mungkin diberikan pada pasien yang melakukan pembedahan baik sebelum atau setelah operasi untuk menciptakan suasana keadaan tenang dan menurunkan kecemasan adalah dengan mendengarkan musik. Tujuan pemberian terapi musik akan membantu pasien mengekspresikan perasaan, mengurangi ketegangan otot dan menurunkan kecemasan secara biologis akan meningkatkan energi otot, menyebabkan frekuensi nafas, nadi menjadi teratur tekanan darah menjadi stabil (Djonan, 2006)

Kecemasan pasien yang akan menjalani operasi pada umumnya meningkat dikarenakan pasien tidak mengerti tentang prosedur pembedahan serta hal yang harus dilakukan setelah pembedahan, untuk membantu mengontrol kecemasan pada pasien melakukan pembedahan yaitu dapat diberikan terapi musik. Pemberian terapi musik adalah salah satu jenis tindakan yang akan mempengaruhi sistem emosional diotak sehingga dapat menurunkan kecemasan (Djonan, 2006)

Hasil penelitian Argi dengan judul pengaruh aromaterapi lavender terhadap intensitas nyeri pada pasien pasca operasi di RS Dustira Cimahi didapatkan hasil penelitian terdapat perbedaan intensitas nyeri yang mempengaruhi kecemasan pasien post operasi dengan nilai $\mathrm{p}$ value :0,00 (Argi, 2013)

Minyak essensial dalam penelitian ini menggunakan aroma lavender dalam menurunkan kecemasan. aroma memanfaatkan fungsi olfaktory sebagai media pengantar rangsangan aroma bau yang dapat menstimulasi sistem limbik di hipotalamus sehingga memicu gelombang alfa untuk memberikan efek relaksasi sehingga diharapkan memberikan pengaruh terhadap penurunan tingkat kecemasan (Susanti, 2005)

Zat utama yang terkandung dalam lavender berupa linalol dan linali asetat merupakan zat yang dapat memberikan efek relaksasi pada saat keadaan cemas dan panik. Efek yang ditimbulkan dari aroma terapi hanya akan mempengaruhi kondisi fisiologi pasien (Susanti, 2005)

\section{Efektifitas Musik dalam menurunkan kecemasan pasien dengan pembedahan laparatomi}

Berdasarkan hasil penelitian menunjukkan penurunan kecemasan yang paling rendah yaitu 9.78 dibandingkan dengan lavender yaitu 10,78, sehingga dapat disimpulkan bahwa terapi musik lebih baik dibandingkan terapi lavender hal ini dika- 
renakan perjalanan gerataran suara lebih cepat mencapai otak dibandingkan aromaterapi sehingga otak lebih cepat merespon terhadap stimulus, selain itu jenis musik yang digunakan adalah musik yang disenangi oleh responden sehingga pasien dapat lebih rileks, pasien diberikesempatan memilih lagu yang telah disediakan yaitu Lalan Belek, Sayang Api Coa Sayang, Anak Kunang, Kebilau Baliak,Sekundang Setungguan.

Hasil penelitian Pratiwi (2009) tentang pengaruh terapi musik klasik terhadap tingkat kecemasan pasien pre operasi di RSUP DR. Soeradji Tirtonegoro Klaten diketahui bahwa terapi musik klasik mempunyai pengaruh terhadap tingkat kecemasan pre operasi. Sebelum diberikan terapi musik klasik 20 pasien mengalami kecemasan ringan yaitu $64,5 \%, 11$ orang mengalami cemas sedang yaitu $35,5 \%$, setelah diberikan terapi musik 19 pasien tidak mengalami kecemasan yaitu $61 \%$, dan 12 orang mengalami cemas ringan yaitu $39 \%$ responden (Direja, 2003)

Tujuan pemberian terapi musik akan membantu pasien mengekspresikan perasaan, mengurangi ketegangan otot dan menurunkan kecemasan yang mana secara biologis akan meningkatkan energi otot, menyebabkan frekuensi nafas, nadi menjadi teratur tekanan darah menjadi stabil (Djonan, 2006)

Banyak jenis musik yang digunakan untuk terapi diantaranya musik klasik, instrumental, jazz, pop, keroncongan, musik daerah dan keagamaan yang memberikan manfaat badan, pikiran dan mental menjadi lebih sehat. Dengan menggunakan musik yang tepat dan disukai pasien akan mempercepat proses penurunan tingkat kecemasan sehingga tidak heran saat ini semakin banyak hasil riset mengenai efek musik (Firman, 2015)

Seperti halnya dalam penelitian ini yang menggunakan musik daerah dengan judul lagu Lalan Belek, Sayang Api Coa Sayang, Anak Kunang, Kebilau Baliak, Sekundang Setuangguan dengan bite 50-70 $\mathrm{x} /$ menit memberikan dampak yang positif dalam menurunkan kecemasan pasien hal

Musik dapat bermanfaat untuk membuat seseorang menjadi rileks, menimbulkan rasa aman, sejahtera melepaskan rasa sakit dan menurunkan tingkat kecemasan pasien yang melakukan pembedahan dan melepaskan rasa sakit dan menurunkan tingkat stress sebelum dan sesudah melakukan operasi (Firman, 2015) hal ini terjadi dikarenakan adanya penurunan Adrenal Corticotropin Hormon (ACTH) yang merupakan hormon stress (Djonan, 2006)

Hal yang akan timbul dikarenakan ansietas adalah nafas pendek (24x/mnt), Irama jantung dan tekanan darah meningkat $(>120 / 80 \mathrm{mmHg}$ ), Gejala yang tidak enak pada lambung (mual, nyeri lambung), Ekspresi muka seperti gugup, bibir gemetar

Hasil penelitian yang dilakukan oleh sartika,dkk dengan judul Efektifitas konseling dan musik religi kristen terhadap kecemasan pasien pre operasi dengan hasil penelitian menunjukkan tidak ada perbedaan efektifitas antara konseling dan musik religi terhadap tingkat kecemasan pasien pre operasi dengan nilai $\mathrm{p}$ :0,630 (Argi, 2013)

Hasil penelitian Anna Fenco et al dengan judul the Influence of ambient scent and music on patients' anxiety a waiting room of plastic surgeon dengan hasil penelitian menunjukan ada pengaruh penggunaan musik dan aroma terapi dalam menurunkan kecemasan pasien di ruang tunggu operasi dengan nilai $\mathrm{p}$ value untuk aromaterapi :0,01 dan nilai $\mathrm{p}$ value untuk musik adalah :0,03 (Anna, 2015)

Penelitian lain tentang efektifitas terapi murotal dan terai musik klasik terhadap penurunan tingkat kecemasan pasien pra operasi di pekalongan yang dilakukan oleh firman faradisi menunjukan hasil terapi murotal lebih efektif dalam menurunkan kecemasan (p:0,000)

Hal ini menunjukan dengan jenis musik yang tepat maka akan memberikan hasil yang sesuai, tidak hanya musik daerah namun musik religi dan klasik bahkan terapi murotal pun akan memberikan kete- 
nangan dan memberikan dampak positif dalam meningkatkan kesehatan pasien.

Hasil analisis statistik menunjukkan secara keseluruhan ada penurunan rerata skor kecemasan antara kelompok intervensi lavender dan kelompok intervensi musik setelah hari ketiga post laparatomi. Terdapat perbedaan yang signifikan penurunan rerata kecemasan antara kelompok intervensi lavender sebesar 15 point dan pada kelompok intervensi musik penurunan rata-rata skor sebesar 18 point, dan hasil perubahan dalam kelompok berarti ada pengaruh terapi lavender dan musik dalam menurunkan kecemasan pasien post operasi hingga hari 3

Musik dapat bermanfaat untuk membuat seseorang menjadi rileks, menimbulkan rasa aman, sejahtera melepaskan rasa sakit dan menurunkan tingkat kecemasan pasien yang melakukan pembedahan dan melepaskan rasa sakit dan menurunkan tingkat stress sebelum dan sesudah melakukan operasi (Firman. 2015). Hal ini terjadi dikarenakan adanya penurunan Adrenal Corticotropin Hormon (ACTH) yang merupakan hormon stress (Djonan, 2006)

Terapi musik yang tepat dapat menurunkan kecemasan pada pasien operasi. Terapi musik merupakan intervensi non invasif yang dapat diterapkan secara sederhana tidak membutuhkan ruang lingkup yang besar dalam pelaksanaannya dan tidak menimbulkan efek samping (Firman, 2015)

Hal lain yang dapat dilakukan dalam menurunkan kecemasan pasien adalah dengan melakukan tehnik distraksi, tehnik distraksi yang mungkin diberikan pada pasien yang melakukan pembedahan baik sebelum atau setelah operasi untuk menciptakan suasana keadaan tenang dan menurunkan kecemasan adalah dengan mendengarkan musik. Tujuan pemberian terapi musik akan membantu pasien mengekspresikan perasaan, mengurangi ketegangan otot dan menurunkan kecemasan yang mana

\section{DAFTAR RUJUKAN}

Anna Fanco and Caroline Loock. The Influence of Ambient Scent and Music on Patient's in a Waiting Room of a Plastic Surgeon. 2014. Penerbit Health Environment Research and design journal. 2014. Diakses 10 Maret 2015 secara biologis akan meningkatkan energi otot, menyebabkan frekuensi nafas, nadi menjadi teratur tekanan darah menjadi stabil (Djonan, 2006)

Hasil penelitian Endah, dkk dengan judul pengaruh tehnik ditraksi relaksasi terhadap penurunan intensitas nyeri pada pasien post operasi laparatomi dengan hasil penelitian ada perbedaan antara pre dan post perlakukan tehnik distraksi relaksasi terhadap penurunan intensitas nyeri post operasi dengan nilai $\mathrm{p}$ value :0,000 dan terdapat pengaruh distraksi relaksai dalam menurunkan kecemasan dengan nilai $\mathrm{p}$ value :0,024 (Estnia, 2011)

Hasil penelitian stania, dkk dengan judul pengaruh tehnik relaksasi dan distraksi terhadap perubahan kecemasan pada pasien post operasi di ruang Irna RSUP Kandou dengan hasil penelitian menunjukan tehnik relaksasi dan distraksi mampu menurunkan kecemasan dengan nilai $\mathrm{p}$ value : 0,001 (Stania, 2015)

\section{KESIMPULAN}

Berdasarkan hasil penelitian dapat disimpulkan bahwa Jenis lagu yang digunakan dalam terapi musik adalah lagu daerah asli Bengkulu dengan judul Lalan Belek, Sayang Api Coa Sayang, Anak Kunang, Kebilau Baliak, Sekundang Setungguan dan penurunan skor kecemasan lebih tinggi terjadi pada kelompok intervensi musik dibandingkan intervensi lavender

RSUD Dr. M.Yunus Bengkulu diharapkan membuat protap dalam mengurangi kecemasan pada pasien yang menjalani pembedahan baik sebelum maupun setelah dilakukan pembedahan dengan menggunakan terapi musik dengan jenis musik daerah dengan judul Lalan Belek, Sayang Api Coa Sayang, Anak Kunang, Kebilau Baliak, Sekundang Setungguan.

Argi Bangun.dkk. Pengaruh Aromaterapi Lavender Terhadap Intensitas Nyeri Pada Pasien Post Operasi di RS Dustira Cimahi. Ejurnal kep soedirman vol 8 no 2 juli 2013 
Brunner and Sudart.Buku Ajar Keperawatan Medikal Bedah. Penerbit EGC.Jakarta. 1997

Data Laporan Ruang OK RSUD Dr. M. Yunus Bengkulu Tahun 2014

Dewi Prima IGA. Penelitian Atomaterapi Lavender Sebagai Media Relaksasi. Penerbit Universitas Udayana. Bali. 2011

Devi Winja Susanti. Pengaruh Musik Terhadap Kecemasan. Universitas Ahmad Dahlan. 2005

Diego AM, Jones Na, Field T. Aromateray Positive Effect Mood EEG Pattern of Ahertness and Math Lamputations. Penerbit International Jurnal Of Neuroscience vol 96. 1998 : 217224

Dinas Kesehatan. Profil RSUD Sragen. 2008

Direja AHS. Buku Ajar Asuhan Keperawatan Jiwa Edisi I. Penerbit Muhamedika. Yogyakarta. 2003

Djonan.Terapi Musik Teori dan Aplikasi. Penerbit Galang Press. Yogyakarta. 2006

Edi Purwanto. Efek Musik terhadap Perubahan Intensitas Nyeri dan Cemas Pada Pasien Post Operasi di Ruang Bedah RSUP Sardjito Yogyakarta. 2010

Endah Estria. Pengaruh Tehnik Distraksi Relaksasi Terhadap Penurunan Intensitas Nyeri Pada Pasien Post Operasi Laparatomi di PKU Muhamadiayah Gombong. Jurnal Ilmiah Kesehatan Keperawatan vol 7 no 1 februarai 2011

Faradisi Firman. Efektifitas Terapi Murotal dengan Musik terhadap Penurunan Kecemasan Pasien Pre Operasi Fraktur Eksternal. http://www.journal.Stikes.Muhamadih.pkj.ac.i d 2012. Diakses tanggal 10 Maret 2015

Firman. Efektifitas Musik Klasik Terhadap Penurunan Tingkat Kecemasan Pasien Pre Operasi di RS Pekalongan. September 2012

Hale G. Lavender Nature's aid to stress relief. www.aromaterapi.stress.relief. 2008. Diakses 10 Maret 2015
Hutasoita Ani. Panduan Aromaterapi untuk Pemula. Penerbit Gramedia Pustaka Utama. Jakarta. 2002

Junaidi, zoikhan Noor. Penurunan Kecemasan Pada Lansia Melalui Musik Langgam Jawa. Penerbit Jurnal keperawatan Indonesia Universitas Muhamdiyah Yogyakarta Vol 13 no 3. 2010

Kasjono Yasril. Tehnik Sampling Untuk Penelitian Kesehatan. Penerbit Graha Ilmu. Yogyakarta. 2009

Lila Prima.Hubungan Kecemasan dan Lama Hari Rawat Pada Pasien IMA. Jurnal Kesehatan Keperawatan UNAND. Agustus 2012

Masood Jawaid et.al. Kecemasan Pasien Pre Operasi di RS Civil Hospital. Karachi. Pakistan. 2006

Pratiwi N, putu Mega. Pengaruh Terapi Musik Terhadap Tingkat Kecemasan Pasien Pre Operasi RSUP Dr. Soeradji Tirtonegoro Klaten. Penerbit http://Skripsistikes.wordpress.com/taq/terapimusik-klasik. 2009

Sawitri. Faktor yang Berhubungan dengan Kecemasan Pasien Pre Operasi di RS Umum Kustati Surakarta. Desember 2012

Shinobi. Pijat Aromaterapi. http://id.88.db.com/id/discussion/health. 2008. diakses tanggal 4 Maret 2015

Stania,dkk. Pengaruh Tehnik Relaksasi dan Distraksi Terhadap Perubahan Intensitas Cemas Pasien Post Operasi di IRNA RSUP kandou Manado. 2013

Stuart And Sundeen. Buku Saku Keperawatan Jiwa. Penerbit EGC. Jakarta. 1998

Wening, Sri Numarni, Ida Aryanti. Aromaterapi Lavender Inhalasi Terhadap Intensitas Nyeri Pasca Secti Caesaria. Penerbit Journal Medica Hospital. 2014 diakses tanggal 2 Mei 2015 